University of Nebraska - Lincoln

DigitalCommons@University of Nebraska - Lincoln

$12-2009$

\title{
Empty Ritual: Young-Adult Stepchildren's Perceptions of the Remarriage Ceremony
}

\author{
Leslie A. Baxter \\ University of lowa, leslie-baxter@uiowa.edu \\ Dawn O. Braithwaite \\ University of Nebraska-Lincoln, dbraithwaite1@unl.edu \\ Jody Koenig Kellas \\ University of Nebraska-Lincoln, jkellas2@unl.edu \\ Cassandra LeClair-Underberg \\ Texas State University San Marcos \\ Emily Lamb Normand \\ Olivet Nazarene University
}

See next page for additional authors

Follow this and additional works at: https://digitalcommons.unl.edu/commstudiespapers

Part of the Critical and Cultural Studies Commons, Gender, Race, Sexuality, and Ethnicity in Communication Commons, and the Other Communication Commons

Baxter, Leslie A.; Braithwaite, Dawn 0.; Koenig Kellas, Jody; LeClair-Underberg, Cassandra; Normand, Emily Lamb; Routsong, Tracy; and Thatcher, Matthew, "Empty Ritual: Young-Adult Stepchildren's Perceptions of the Remarriage Ceremony" (2009). Papers in Communication Studies. 119.

https://digitalcommons.unl.edu/commstudiespapers/119

This Article is brought to you for free and open access by the Communication Studies, Department of at DigitalCommons@University of Nebraska - Lincoln. It has been accepted for inclusion in Papers in Communication Studies by an authorized administrator of DigitalCommons@University of Nebraska - Lincoln. 


\section{Authors}

Leslie A. Baxter, Dawn O. Braithwaite, Jody Koenig Kellas, Cassandra LeClair-Underberg, Emily Lamb Normand, Tracy Routsong, and Matthew Thatcher 


\title{
Empty ritual: Young-adult stepchildren's perceptions of the remarriage ceremony
}

\author{
Leslie A. Baxter
}

University of Iowa

\section{Dawn O. Braithwaite \& Jody Koenig Kellas}

University of Nebraska-Lincoln

\section{Cassandra LeClair-Underberg}

Texas State University San Marcos

\section{Emily Lamb Normand}

Olivet Nazarene University

\section{Tracy Routsong \\ Washburn University}

\section{Matthew Thatcher \\ Arkansas State University}

Corresponding Author: concerning this article should be addressed to Leslie A. Baxter, F.Wendell Miller Distinguished Professor, Communication Studies, 105 BCSB, University of Iowa, Iowa City, IA 52242, USA [e-mail: lesliebaxter@uiowa.edu].

\begin{abstract}
This qualitative study investigated 80 young-adult stepchildren's talk about one of their parents' remarriage ceremony. The remarriage event was celebrated in six types of ritual enactments, five of which celebrated the couple's marriage and one of which was familycentered in its celebration of the beginning of the new stepfamily. Three factors led stepchildren to find the remarriage ceremony empty: (i) a ritual form that was too traditional or not traditional enough; (ii) a ritual enactment that failed to pay homage to either the stepchild's family of origin or the stepfamily as a unit; and (iii) a ritual enactment that failed to involve the stepchild prior to and during the ceremony. Results support the characteristics of empty rituals posited in ritual theory.
\end{abstract}

Keywords: family ritual, relational dialectics, remarriage ceremony, stepfamily 
Family rituals are deep-rooted communication events characterized by repetition, prescribed form, and homage to an aspect of family life (Baxter \& Braithwaite, 2006; Bossard \& Boll, 1950; Cheal, 1988; Wolin \& Bennett, 1984). Baxter and Braithwaite (2006) defined a family ritual as a 'voluntary, recurring, patterned communication event whose jointlyenacted performance by family members pays homage to what they regard as sacred, thereby producing and reproducing a family's identity and its web of social relations' ( $p$. 263). Scholars have increasingly turned to rituals as a way to understand communication in family life (e.g., Altman, Brown, Staples, \& Werner, 1992; Baxter \& Braithwaite, 2002; Braithwaite, 1995; Braithwaite \& Baxter, 1995; Braithwaite, Baxter \& Harper, 1998; Bruess \& Pearson, 1997; Werner, Altman, Brown, \& Ginat, 1993).Wolin and Bennett (1984) stressed that family rituals both perpetuate and transform families. Rituals provide a sense of family identity and 'a bridge between generations' (Fiese, 1992, p. 151). Bossard and Boll (1950) argued that families accomplish their 'emotional business' in their ritual enactments. Most scholars have focused on rituals that have been successfully enacted: Those that are regarded as meaningful and positive for families, and those that increase health and wellbeing (e.g., Bennett, Wolin, Reiss, \& Teitlebaum, 1987; Bruess \&

Pearson, 1997; Deinham, 2003). The current study complements existing ritual work by examining a ritual form experienced as problematic by at least some of its participants: The remarriage ceremony of a parent and the stepparent from the perspective of stepchildren.

\section{Remarriage rituals}

Scholars studying rituals in a variety of disciplines have often relied on Wolin and Bennett's (1984) typology of ritual forms: Celebrations, traditions, and patterned family interactions. Celebrations are rituals that are widely enacted across a culture, for example, holidays like Easter or July 4th, and rites of passage, such as a wedding or college graduation. While there are practices common to celebrations across a culture, families will adapt these rituals in unique ways. Traditions are rituals tied to a family's unique calendar, for example, family members' birthdays or anniversaries. Last, patterned interactions are those routinized practices in day-to-day life that hold meaning for family members, for example, family breakfast and bedtime rituals.

The wedding is one important family celebration ritual that is practiced widely and holds deep meaning for the marital couple (Holmberg, Orbuch, \& Veroff, 2003; LeedsHurwitz, 2002). Most research on courtship has centered on first marriages without children (Cate \& Lloyd, 1992), and scholars have examined weddings typically as first-marriage ceremonies (e.g., Leeds-Hurwitz, 2002). Although it is important to study first-time marriages, remarriages are on the rise in the United States. Ganong and Coleman (2004), for example, reported that $30 \%$ of divorced persons marry within a year of the divorce.

The remarriage ceremony may be more complex compared with the first-time ceremony, because one or both partners may enter the new marriage with children from one or more previous relationships (Ganong \& Coleman, 2004). While researchers and clinicians have studied stepfamily formation, their work has focused on dating and cohabitation, couple dynamics, and the characteristics of remarried families (e.g., Ganong \& Coleman, 2004). Researchers have yet to study the stepfamily's remarriage ritual, the occasion when the stepfamily becomes formalized through marriage of the adults. A description of the different types of remarriage rituals thus serves as the first research question for the current study:

RQ1: What are different types of remarriage ceremonies enacted in stepfamilies? 


\section{Meaningful and empty rituals}

Most scholars appear to start with the presumption that family rituals are most often functional and pleasant, and they have done little to understand the potentially darker side of family rituals (Baxter \& Braithwaite, 2006). Wolin and Bennett (1984) coined the term 'empty ritual' to describe rituals that are not positive or meaningful for participants. Similar to Turner's $(1957,1969,1974)$ anthropological work on rituals, they argued that meaningful rituals would be characterized by two key features (and by implication, empty rituals would not have these characteristics). First, meaningful rituals were thought to feature participants' high commitment to the act of ritualizing: The ritual is valued as an opportunity to celebrate common family identity and its continuity from past to present. Second, Wolin and Bennett (1984) argued that meaningful rituals would display flexibility and adaptability in response to individual or situational needs.

Dialectically oriented family ritual theorists have argued that rituals are likely to be meaningful to the extent that they pay homage to contradictory themes. Altman and his colleagues (e.g., Altman \& Ginat, 1996; Brown, Werner, \& Altman, 1998; Werner et al., 1993) emphasized a ritual's ability to explore, develop, and celebrate the individual-collective dialectic. Baxter and Montgomery's (1996) relational dialectics theory opened up ritualizing to include all contradictory themes, including but not limited to the individual-collective dialectic (Baxter, 2004).

Although family ritual theorists have posited three characteristics that differentiate meaningful from empty rituals - commitment to the act of ritualizing, adaptability, and homage to contradictory themes - research on empty rituals is quite limited. In a rare study comparing meaningful and empty rituals, Braithwaite and her colleagues (Braithwaite et al., 1998) studied ritual enactments other than the remarriage ceremony in stepfamilies, and found that efforts to import old family rituals that honored the original family but did not speak to the stepfamily as a unit often failed. In contrast, families that were willing to adapt old ways of celebrating to fit the needs of the stepfamily found that they could successfully import old family practices. Whereas this study considered how families needed to adapt their rituals over time, few scholars have focused on the fact that some rituals might be, from their inception or original enactment, meaningful for some family members while empty for others. One exception is Oswald (2000), who discovered that non-heterosexual family members' participation in the heterosexual family wedding ritual often found themselves disenfranchised from these events.

To date, little is known about the differences between those rituals that participants do and do not find empty. Remarriage rituals, the wedding event of a parent and stepparent, provide an opportunity to study factors that can influence whether a ritual event is experienced as empty. While the marrying couple presumably anticipates their wedding as a positive celebration, it is not clear that the children associated with the remarriage event share the same understanding. Ganong and Coleman (2004) pointed out that researchers know little about the involvement of children in the courtship of their parents and stepparents, a period that is often relatively short and often includes surprisingly little preparation for remarriage and stepfamily status. As little as researchers know about courtship, even less is known about the parent's remarriage ritual and the stepchildren's involvement in it. Thus, in the present study we elected to focus on stepchildren's perspective on the remarriage ritual of parents and stepparents. This focus on stepchildren's perspective responds to the call of several scholars for more research from the perspective of stepchildren (e.g., Amato, 1994; Coleman, Ganong, \& Fine, 2000). The second research question for the study is thus: 
RQ2: What characteristics differentiate meaningful from empty remarriage events from the stepchildren's perspective?

\section{Methods}

\section{Participants}

Volunteer participants were recruited through the venues of two large Midwestern academic institutions, consistent with their respective institutional review boards. Eligibility for participation in the study was having a parent who remarried within the 10-year period prior to the interview. The average age of participants was 21.7 years $(S D=2.3)$. The sample was largely Caucasian (97.5\%). The average number of years since the remarriage event had transpired was 7.1 years $(S D=3.7)$. Eighty completed interviews were gathered: 30 from male participants and 50 from female participants.

\section{Data collection procedures}

The data were gathered through semi-structured, focused interviews. Four of the researchers served as interviewers for the study, each completing 20 interviews. Although the interviewers used an interview guide, they had the freedom to pursue relevant topics as appropriate (McCracken, 1988). Participants were assured of their confidentiality. Interviewers asked and received permission to audio-record the interviews, which were digitized and later transcribed. The interviews lasted approximately one hour each. Participants provided the researchers with demographic information about their respective stepfamilies, including their perceptions of when the stepfamily formed, and they completed a demographic family tree to describe the composition of the stepfamily as well as the family of origin. The interviewers then engaged the participants in a discussion of the development of their respective stepfamilies. They were asked in an open-ended fashion to tell the story of the stepfamily's development, with the interviewer asking follow-up probe questions. Most relevant to this study were the questions focusing on the remarriage event itself. Participants were asked in an open-ended manner to tell the story of the remarriage event, and then they were probed about how they felt about that event and how closely it matched their ideal. Emphasis was placed on soliciting the subjective perspective of the participant in as much detail as possible.

\section{Data analysis procedures}

Data were transcribed for purposes of analysis and then loaded onto ATLAS.ti, a qualitative software program that assists in the management of textual data. The lead author began the data analysis process by reading through all of the transcripts several times in order to gain familiarity with the data set as a whole. Analytic coding (Lindlof \& Taylor, 2002) was used to identify categories responsive to the two research questions. For RQ1, code categories were developed from the data responsive to the analytic question, 'What are different types of remarriage ceremonies?' For RQ2, code categories were developed from the data responsive to the analytic question, 'What are the reasons why the remarriage ceremony was evaluated as positive or negative by the participant?' Analysis of the second research question focused on participant evaluative reactions to the remarriage ceremony. Analytic coding is an inductive process in which a given textual segment is compared to prior data segments for its similarity or difference. A 'segment' is any textual fragment that provides an answer to an analytic question, and segments can vary in length 
from phrases to paragraphs. Each time a given segment was perceived as different from prior data segments, a new coding category was added. Analytic coding is also iterative, as coding categories were added, combined, and revised in an emergent manner until the coding categories as a set did not require further modification with additional cases. The derivation of coding categories reached saturation at interview \#50; that is, no new coding categories were added to the analysis after that interview.

The second stage of analytic coding involved finding connections among the coded categories, winnowing down their number by clustering together similar categories into a coherent analytic set. Coding categories were combined to produce larger family networks of codes. These are detailed below in the Results section.

The lead author drafted a preliminary articulation of the findings, including illustrative exemplars from the data set.This document was then shared with all of the interviewers in order to perform the credibility check known as investigator triangulation (Lincoln \& Guba, 1985). In this study, investigator triangulation took the form of asking each interviewer to assess the analysis against their respective sub-sample of 20 interviews, determining whether it adequately represented their data. All four interviewers indicated that the results adequately represented their respective interviews.

\section{Results}

\section{Types of remarriage ceremonies}

The first research question focuses on the various types of remarriage ceremonies. Six different forms were identified in these data. The first five types pay primary homage to the marrying couple, whereas the last type is a stepfamily- centered ceremony in which the stepfamily as a unit is honored.

The white wedding. Leeds-Hurwitz (2002) used the term 'white wedding' in reference to the dominant American tradition of first weddings. White weddings reference the traditional color of the bride's wedding gown (which symbolizes the chastity of the bride), usually envisioned as part of a large, formal event which is presided over by a minister or priest, with an assortment of attendant roles (e.g., best man, maid of honor), followed by an organized reception attended by family and friends of both the bride and the groom, where a wedding cake is consumed along with other food, and entertainment of some kind is provided. The prototypical white wedding takes place in a church, although other suitable locations are appropriate (e.g., a gazebo as part of a formal, outdoor ceremony). Remarriage ceremonies replicated white weddings for 20 of the stepfamilies in our sample. Participants used a variety of terms to reference this type of ceremony, including 'white wedding,' 'traditional wedding,' 'normal wedding,' 'regular wedding,' 'real wedding,' and 'the fairy-tale wedding.' Many of the 'white weddings' in our data set involved offspring from the respective first marriages serving as members of the wedding party. Although offspring were given a formal role in these ceremonies, the 'sacred object' of the ritual was still the marrying couple; thus, these events were marriage-centered, in contrast to the family-centered ceremony type we will describe below. Sometimes, however, offspring were given no formal role in the wedding ceremony, functioning instead as audience members who observed the ceremony but did not participate in it.

The modified white wedding. This second type of remarriage ceremony was reported in 25 of the participant accounts and was the most common kind of remarriage ceremony. It was 
a planned event presided over by a minister or priest, usually held in a church or other location deemed appropriate to the seriousness of the event, with designated wedding roles of 'bride,' 'groom,' and attending friends and family (e.g., 'ring bearer,' 'maid-of-honor,' 'best man,' and so forth). A reception, usually informal, often followed the actual ceremony. However, the white wedding was modified in one or both of two ways: (i) it was smaller in scale; and (ii) formal wedding attire was altered. Modified white weddings were notably smaller in size than the white wedding ceremonies: Churches (or alternative locations) were smaller; wedding parties were smaller; the number of guests was smaller; and the follow-up event was more likely to be described as a smaller reception. Attire was modified in several ways that suspended the formal, white wedding gown motif. Representative of both of these modifications is this description of a ceremony provided by a 20 -year-old female participant of her mother's marriage to her stepfather when the participant was 11 years old:

P: I was like the equivalent of a bride's maid, only the little kid's equivalent [laugh] of a bride's maid. It was very, very small.

\section{I: So did you stand up, were you standing up?}

P: Yeah, [her stepsiblings] and [her stepfather], I think that was it, and all of our family members were like just in the first two rows at the church.

I: OK, and what kind of, was it like a traditional ceremony?

P: Like yeah, they had tuxes on and we had dresses on, but my mom had on, she had on just like kinda a white outfit, um not really a wedding dress. Um, the ceremony was very quick. Well, weddings seem to be very quick, but I just remember there wasn't a lot of talk after. It's just kinda, 'We're in, we're out, we did it, we're done.' (\#68)

This wedding was traditional, in that it was in a church and participants dressed up, presumably in fairly formal attire, given the references to 'tuxes.' The mom's dress was white, but this participant noted that it was not an actual wedding dress. The guest list was small - immediate family filling only the first two rows at the church. In this participant's memory, the actual ceremony was shorter than a traditional wedding; they were 'in' and 'out' quickly.

Like the white wedding ceremony, the modified white wedding ceremony found offspring of the respective marital partners either involved formally in the ceremony, as in the example above, or merely attending as audience members. Involvement of the offspring was more common.

If the bride wore a white gown, participants usually qualified this by telling the interviewer that it was not a traditional white wedding gown, unlike the gowns worn in the white wedding ceremony, as stated in the example above. However, if a traditional white wedding gown was worn, it was often the subject of qualification or criticism. Typical is this excerpt from an interview with a 19-year-old female participant, who described her stepmother's gown this way: 'She wore, uh, a white [laugh] wedding dress, which is kind of comical. It wasn't like a traditional one but it was, it was a white wedding dress' (\#62). The participant elaborated that she considered the use of white comical because it was the stepmother's second marriage and the first marriage had produced children. 
Civil ceremony. Eight of the participants described a third type of remarriage ceremony that was presided over by a non-religious official with legal authority to perform marriages. Many civil ceremonies took place in courthouses. Courthouse ceremonies were often quite small, perhaps consisting of only the couple, the official, and legal witnesses. The celebration portion of the event typically occurred separately from the legal portion. For many participants, the celebration event occurred upwards of several months later, at a time more convenient to everyone.

Some participants provided accounts of the civil ceremony that implied the inappropriateness of a white wedding or a modified white wedding. One 21-year-old female participant told us that, 'They did, um, a courthouse wedding. Because they didn't want to deal with a big, you know, they're older' (\#50). Another participant, a 24-year-old male, told his interviewer that his mother and stepfather had decided in favor of a civil ceremony because the marriage was only a matter of legality: 'They, it seemed like the ceremony was just kind of, matter of fact, like, and that's how they approached it. They didn't want a big thing. They just wanted to, you know, basically have it legalized' (\#51).

Sometimes civil ceremonies took place in locations other than courthouses. These were typically embedded in events that were at once legal marriage ceremonies and celebrationcentered parties. Typical is this account provided by a 22-year-old female participant describing the remarriage civil ceremony of her father and stepmother:

They were married, since my dad and my mom were divorced, they couldn't get remarried in a church. So ah, they rented out the skyboxes here at the [rival university] football game, when it was at [rival university] and they had like a full-blown like tailgate wedding. Like it was almost ridiculous [. . . But, uh, so that's what they did. (\#6)

This account also provides insight into another reason couples were perceived to choose civil ceremonies - their divorced status precluded remarriage in a church.

Casual event. Sixteen participants described a fourth type of remarriage ceremony that can best be described by its casual quality. These were presided over by either a justice of the peace or a minister. Most typically, they were highly informal events, often located in home-like environments, with a very simple ceremony. Post-celebration events often involved serving food in the home or adjourning to a restaurant for a non-reception-like dinner. Typical of the informality of this event is this description provided by a 19-year-old male participant of his mother's and stepfather's marriage:

Well, my mom and stepdad's wedding took place, actually we live on an acreage outside of Omaha and it took place in our front yard [. . . It was just kind of a friends and family type, and I remember, probably the most significant thing was my little brother, my first little [half-]brother had just been born, right around the same time. So, it was my mom going through the hassles of having a newborn baby and trying to have the wedding and having to run back into the house. (\#25)

This event took place at home and was so casual that the participant's mother could interrupt the ceremony to engage in care-taking of her newborn baby! 
Elopement. The fifth type of marriage-centered ceremony was elopement, reported by eight participants. The marital pair went away to get married, typically in a civil ceremony but occasionally by a religious official. Occasionally, family members were informed that the event was imminent; more typically, they were informed after the fact that the marriage had occurred. One 21-year-old male participant described the elopement of his father and stepmother this way:

It wasn't a ceremony. They went down to Hot Springs, Arkansas, and found a preacher and got married out in the park. They had some random people be the witnesses, and that was that. And I got a call about it, and I don't know, I didn't really care. I knew it was probably going to happen. I thought it was a little fast and rushed. (\#41)

Family-centered ceremony. Least common in our data was a sixth type of remarriage event that we are labeling family-centered, because the sacred object to which homage was paid was the stepfamily unit rather than the marital couple per se. Only three participants described this kind of event, but it was deeply meaningful to them - a point to which we return in addressing RQ2. Representative is this account provided by a 20-year-old female participant whose mother married her stepfather in a casual ceremony held at a local Bed \& Breakfast: 'All three of us girls [the participant and her two stepsiblings] were in the wedding and we all got little rings to show that we all got married. We got rings' (\#1). This participant informed us that prior to the ceremony the family had gone through marital counseling sessions, in which all of the children had been actively involved in discussing with their priest what it meant to form a new family unit. Thus, to this participant, the ceremony was not only a marriage between the two adults; it was the 'marriage' of the entire family unit - two adults and three daughters.

In sum, our sample of young-adult stepchildren reported six basic types of remarriage ceremonies. Five were centered on the marital pair: The white wedding; the modified white wedding; the civil ceremony; the casual event; and the elopement. The last type - the family-centered ceremony - was least common and involved homage to the whole stepfamily unit, including the marital pair and all of the stepchildren.

\section{Meaningfulness of remarriage ceremonies}

The second research question focused on the meaningfulness of remarriage ceremonies, asking what characteristics differentiate meaningful from empty enactments. Meaningfulness was contingent on three basic factors: (i) the type of ritual enactment; (ii) the legitimation granted to the 'sacred object' (most typically the marriage), and (iii) the degree of involvement stepchildren had in the ceremony. We address each of these in turn.

The type of ritual enactment. The six types of ritual enactments identified in response to RQ1 were not regarded as equally appropriate by our participants. The type of ceremony was important to many participants in helping to make the remarriage ritual more or less meaningful. In general, participants endorsed what we might call the 'Goldilocks principle' of remarriage ceremonies: They should have some elements of a traditional wedding, but not too many. Ceremonies that violated this principle were found empty by the stepchildren.

Our young-adult stepchildren were most critical of the white wedding. This evaluation was evidenced in two ways: Approval of ceremonies that were not white weddings, and 
criticism of parental decisions to marry in a white wedding ceremony. Typical of this evaluative stance toward the white wedding is this excerpt from a 20 -year-old female whose mother had remarried two years previously in an elopement, followed by a big party at a later date:

I think it [eloping] was the right thing to do. Um, I think that's exactly what they needed. You know, first wedding you do the traditional, let's invite family, let's invite friends, everybody, have the big shindig. But it was the second wedding and they had been together for three years, and it was just kinda like, you know what, let's just go have fun. (\#57)

This excerpt addresses two themes that appeared in the data. First, many participants believed that big, formal 'white weddings' were appropriate only for first-time marriages. As another 20-year-old female participant told her interviewer, 'They were both like second marriages, like my mom's [remarriage] wasn't that big and extravagant because it's her second marriage and they both had kids, which would have been kind of inappropriate I think' (\#7). Second, because the couple had already been living together for a substantial length of time, the wedding did not symbolize the formation of a new relationship so much as a formalization of it.

Several participants were even critical of a modified white wedding ceremony if its modifications were insufficient. Typical is this account by a 23 -year-old female participant whose mother had remarried nine years prior to the time of the interview:

I didn't think it should have been such a big to-do as it was. Now, it wasn't huge with hundreds of people. It was very intimate, but, you know, having it in a church, having it in a, having the, the dress and the veil, and the tiered cake, and the bridesmaids and this and that, I, it's like I feel the relationship didn't deserve that and that might sound cold because my mom, you know, she was happy at the time. (\#48)

A different reason for departing from the white wedding tradition was provided by the following participant, a 21-year-old female whose father remarried in a family-centered, very small ceremony. This participant's remarks are critical of any marriage-centered ceremony:

[The stepmother] came and she had like talked with us about it and said that she wasn't there to, like, replace anyone and that she wanted to, like, all of us be, like, part of her family, so that's why she included us in the wedding [. . .]. [She] included us in the wedding and, I don't know, having the small wedding was nice because, since we were included in the wedding we would be standing up there with them the whole time, it would have been a little uncomfortable for, like, all of, like, my mom and dad's joint friends to come and see the wedding knowing that there's another woman up there with my dad. (\#53)

By focusing on the stepfamily, the ceremony deflected attention away from the ghost of the former spouse in the minds of guests. Perhaps this deflection also functioned positively for the participant based on her first statement:That the stepmother was seeking to focus on the stepfamily and not to position herself as a replacement mother figure. 
But the type of ceremony was a complicated contingency for the stepchildren in our sample. On the one hand, the ceremony could be criticized for being too traditional. However, several participants also criticized the remarriage ceremony because it was not traditional enough. Civil ceremonies were criticized by some participants, who wished for a more religion-based ceremony.Typical is this excerpt from a 20-year-old male participant whose mother remarried in a civil ceremony: 'If it had been ideal it probably would have been better to be a Catholic wedding just because that's what I believe in and stuff' (\#32). Other ceremonies were critiqued for being too casual. Representative is this account by a 24-year-old male participant, whose father remarried in a casual civil ceremony that was part of a barbeque party:

P: The way they did it, it was like it was no big deal, because they had lived together so long I think it was really just a, a formality. That's why I don't think his family took it seriously. But like they wanted to have everyone take it seriously, but they did it in, so casual that it seemed like it didn't, um, really mean like much.

I: So you would have wanted a more uh traditional wedding?

P: Well, if you want everyone to take it seriously, it needs to be a little more than um, a barbeque. (\#77)

Unlike the participant quoted earlier, who found white weddings inappropriate because the pair had already been living together, this participant expressed the opposite view evident in the data: Because the pair had lived together, they needed something more formal to mark the marriage as an important event. Both views were evident in the data set as a whole.

Elopement and impersonal civil ceremonies were also subject to criticism, largely because they precluded the presence of family and friends whose attendance would have functioned to mark the event as significant by bearing witness. As one 21-year-old female participant remarked in response to an interviewer query about how the ceremony might have been different if it were ideal: 'I feel like I would try to encourage them to have, like, a bigger wedding with at least, like family [. . .] Just because it makes the moment so much, you know, better and you have so many people to celebrate with and stuff' (\#59).

In addition to experiencing the type of ceremony as problematic, our participants also experienced the ritual as empty because of the sacred object it celebrated - the newly married couple.We turn next to a discussion of this source of emptiness.

Legitimation granted to the marriage. The majority of participants found it difficult to legitimate the remarriage. Since the ceremony, for the most part, was focused on honoring the new marital couple, it was difficult for participants to experience the ritual as meaningful; its sacred object - the marriage - was not accepted as worthy of homage. Although some of our participants liked the new stepparent and were happy about the remarriage event, the majority were not supportive of the remarriage, which undermined its legitimacy. Several reasons were expressed by our participants in explaining why they did not legitimate the remarriage of their parent to the stepparent.

Some of our participants were estranged from their remarrying parent and had lim- 
ited interactions with him or her.These participants were largely indifferent to the remarriage. One 23-year-old male participant found out through his mother that his father had remarried. His reaction to the remarriage was typical of our estranged participants:

I: What was it like for you to find out your dad had gotten married?

P: It was like, um, I well, I didn't know who he married [. . .] Well, he could have told me before he got married, but it still might not have made much of a difference. It's not a decision that changed my life much or anything

[. . . It didn't really make a difference because it wasn't like we were really talking. (\#78)

The majority of participants who had ongoing contact with the remarrying parent had difficulty legitimating the remarriage of a parent for four basic reasons: (i) a sense that the decision to wed was too hasty; (ii) dislike of the new stepparent; (iii) skepticism that the parent could sustain a successful marriage to anyone; and (iv) mourning at the demise of their parents' marriage. We will illuminate each of these reasons in turn.

Many participants felt that the marriage was premature or hasty. Over and over, participants expressed a sense that they had insufficient time to get to know the new stepparent, his or her extended family, and the new stepsiblings. One typical reaction was expressed this way by a 20 -year-old male participant whose father had remarried when the participant was 11 years old:

Ah, it was kind, well it was really abrupt and there wasn't much, like I said the beginning of the relationship was really abrupt, where they met each other and they were dating for a short period of time, they clicked so well that she moved in with him. And ah, we didn't know anything [. . .] So it was just like all of a sudden our world just turned upside down. And I wish we would had [sic] more of a period of orientation of where we could talk with her and meet her and get to know her [. . . ] It was just kind of thrust upon us. (\#39)

This theme of haste was echoed with respect to the stepparent's family. A 24-year-old female participant described for us how she felt at the party following her $\mathrm{f}$ ther's remarriage in a civil ceremony, where she was surrounded by three new stepsiblings and a host of extended step-relations:

All the stepfamily was there [. . .] and it was just like everything was happening so fast, and like, I guess for me I was a little confused about having all these new people being a part of my life and I didn't know any of them. And like I was 17 at the time so, I mean, it wasn't like I was a kid [. . .] I just can remember being really confused about that and, and like, people talking to me and just, like, why are you talking to me? (\#63)

Other participants found the decision to wed hasty because it came so quickly on the heels of the parents' divorce. As one 22-year-old male participant told us, 'He had the wife for 35 years, and so it was only six months they were together, and then right away, it was like 'I'm going to get married to this girl,' and I was like "whoa!"' (\#42). 
The remarriage lacked legitimacy for other participants because they felt they knew the stepparent and disliked him or her. Sometimes, this dislike was rooted in jealousy of a stepparent, as this account by a 19-year-old female participant reveals:

And I wasn't very happy about that [the marriage], of course, because before this, you know, we got to spend a lot of time with my dad. He would pay more attention to us. But then when she came into the picture it was just, you know, he didn't spend as much time with us or so, we kind of got left out. (\#22)

Other participants simply disapproved of having the person as a stepparent. As one 20-year-old female participant succinctly put it, 'We didn't relate [. . .] just very different lifestyles and very different ways of thinking' (\#15).

Several of the participants expressed skepticism that the remarriage could succeed because they lacked confidence in the parent's ability to ever sustain a successful marriage. These participants often had been through multiple remarriages involving one or both parents. Some also perceived that the remarrying parent had problems that interfered with the ability to marry (e.g., drug or alcohol problems). Such skepticism made it difficult for the participant to take the remarriage very seriously. This account of a mother's remarriage, provided by a 25-year-old female participant, is typical:

I: How did you feel about the whole remarriage event?

P: To be honest, she'd been married so many times it didn't mean anything [. . . I It had lost all, I, I couldn't even get excited about it [. . .] It was painful to even watch with the rest of my family, pretend like this was something significant. You know? Um, it just sort of felt like no one, everyone was ignoring the elephant in the room so to speak, like, this is my mother's fourth marriage, and, like, she didn't have her [act] together yet. (\#61)

Many participants were assaulted with powerful emotional reactions that revealed the mourning they were still experiencing for the family of origin. For these participants, the remarriage was an offense to their memories of the way life used to be. Some participants regarded the remarriage as a harsh realization that their desire for the parents to get back together was not going to be fulfilled. As one 20-year-old female participant told us about her father's remarriage that occurred two years prior to the interview:

Like, I, it didn't hit me until I hung up the phone and then I remember just crying and I couldn't understand why I was crying. You know? And I think it had just hit me that my parents are never going to get back together. Not that I thought that they would, but [. . . I I think I realized that now I have two separate families. Now it's like, it's really happened, you know? And even though they were separated, it just wasn't, you know, but um, I just remember crying and just feeling like this is the worst day ever and I, I didn't understand why, but, you know, you think about it and you're like, well, I guess it did hit you at some level, like, you, I had never thought that them getting divorced was the end of them. (\#65) 
This participant's reaction was typical of many - a sudden realization that the parents' divorce was, in fact, final.

Some participants believed that the remarriage ceremony itself was insulting to their respective families of origin. One 19-year-old male participant shared this account of his feelings at the remarriage ceremony of his father three years prior to the time of the interview:

My brothers and I had, it didn't affect us, but, being there at the wedding and watching my dad get married, and it was, well, the only part that upset me was the pastor was talking about how life's events lead you up to this moment and how there's bumps in the road, and blah, blah, blah, but this is where you're supposed to be. And I got pissed, because I was like, was my mom the bump in the road? Was she the pain in the ass? (\#62)

Other participants reported that the remarriage made them 'uncomfortable' or 'sad' because it made them think about their parents' marriage. Representative is this excerpt from an account provided by a 20 -year-old female participant about her mother's remarriage that took place two years before the interview:

Ah, I'm very, I cry really easily, and at that time I tried to not because, you know, like I said I wasn't very into it, didn't know how right it was, but I was like, you know, my mom wants to do this, I'll support her. I tried not to, but when they gave their vows to each other, I was not happy. It was just because, you know, I was thinking about stuff and like my mom made these vows to my dad, like how can she make them to somebody else. Like it just kind of hit me right at that point. (\#15)

This participant, like many others, felt saddened to be at a ceremony where a parent was displaying a serious commitment to someone other than the participant's other parent.

A third factor in why our participants experienced the remarriage ceremony as empty was their level of noninvolvement in the ceremony. This final factor is discussed next.

The involvement of stepchildren in the ceremony. The majority of participants had strong reactions about their involvement in the remarriage event. Some participants were pleased with their involvement in the ceremony. However, over and over again, participants told us that they had wanted far greater involvement with the remarriage event, with the exception of those children already estranged from the remarrying parent, as discussed above. The meaningfulness of the remarriage ceremony was contingent on the type and extent of involvement that stepchildren experienced in both the pre-ceremony stage and during the ceremony itself. A fully meaningful remarriage ceremony was characterized by parents and stepparents who informed and consulted with the stepchild about the decision to marry. A meaningful remarriage ritual was characterized by active involvement of the stepchild in planning the ceremony and in participating in the ceremony in a way that paid homage to their role as a member of the stepfamily unit without de-legitimizing the family of origin. We illuminate these themes by discussing involvement at the two stages of the remarriage event: (i) Preceremony involvement in being informed and consulted about the marriage and the ceremony; and (ii) involvement in the enactment of the ceremony itself.

Many participants were critical of the remarriage event because they were often left uninformed and felt as if their feelings about the event didn't matter. Representative is 
this statement from a 20-year-old female participant whose mother had remarried one year prior to the time of the interview. The participant heard about the decision to remarry as a rumor from the daughter of her stepfather-to-be:

If people are thinking about starting a stepfamily, they should take their time and, you know, keep everyone informed and pay attention to everyone's feelings. I mean, I, I never once during the process had a serious talk about (pause) everything that was, um, going on. I mean, that seems like something a mother should do. Like, talk to her daughters and see how we, um, feel, and take those feelings into consideration. (\#66)

This excerpt stands in marked contrast to the following account provided by an 18-yearold female participant, who felt informed and consulted in her mother's decision to remarry: 'I think it started out in a good manner, and I think that she always took us kids, our feelings, our emotions, into account before anything else' (\#43).

Several participants wanted to be kept informed and consulted not only by their parent but by the stepparent as well, as this excerpt from an account by a 22-year-old male participant illustrates:

I guess, for me, I guess I kind of wanted my stepdad, before he actually asked my mother to marry him, to, to talk to me about it first and to say, 'Hey, you know, I'm thinking about,' I mean [. . . I I think it would have been a lot better if he just said 'Hey, I want to marry your mom and things are going to be different. What do you think about that?'. (\#74)

In stark opposition is this account by a 19-year-old female participant who perceived that her stepparent engaged in adequate consultation:

My stepdad talked to us about how we felt about it - like me and my brother about if he were to marry my mom. He kind of talked to us about it before he, we talked to her about it. And then when he proposed, they both talked to all three of us [herself, her brother, and her stepsister], like they sat all three of us down. (\#80)

Many participants also felt that they were inadequately involved in the planning of the remarriage ceremony.A 20-year-old female participant bemoaned the fact that she felt left out of the planning and preparation for her father's remarriage ceremony:

I think that it would have been ideal if we would have been more a part of it. Like, once again, if we would have known what was going on then it would have been fine [... .] If they sat down and told us, like, 'OK, we want to have this type of a wedding and what do you guys think, that we should have that?' . (\#67)

Accounts such as this one are sharply contrasted with the following account from a 21-year-old female participant, who told the interviewer:

We were included in every step, every process throughout the entire ceremony and preparation. And after, the reception was not really like the celebration of 
the marriage as more like the union of our family, like the uniting of our family which was really unique [...] But it was more people focused on our new family, not my mom's new marriage. (\#81)

This latter participant was involved in a family-centered ceremony.

Several participants who were not in attendance at the ceremony - the case with elopements and many civil ceremonies - wished they had been there. Illustrative is this comment from a 20-year-old female participant whose father had remarried nine years prior to the time of the interview: 'Even just to be there [ . . . Since I'm going to be part of that family, and everything, I wish that we could have just been there' (\#49).

Other participants were in attendance at the ceremony but felt as if their involvement had been symbolically empty. Representative is this excerpt from an interview with a 19-year-old female participant whose father had remarried two years prior to the time of the interview:

I think at the wedding it would have been more ideal if like family members had, I don't know, I guess, paid more attention to me and my brother. 'Cause they were kind of like, oh, you're married and you're going to have kids and everything, but they kind of forgot that there's already two kids in this family. So if that had happened I might have been more comfortable with accepting her family into my family. (\#22)

This participant felt erased by the ceremony and how she was treated. A 25-year-old female participant whose mother had remarried four years prior to the time of the interview echoed this same symbolic emptiness: 'I would have liked to have felt as though there was some, like, a family had been created, or like it was, you know, solidifying or memorializing some kind of bond between, between them and between all of us' (\#61). Such symbolic emptiness was present whether the stepchild was merely a spectator at the ceremony or stood up with a parent as part of the wedding party. Clearly, only the family-centered ceremony was exempt from this feeling of emptiness with their involvement in the ceremony.

\section{Discussion}

This study was an interpretive analysis of the remarriage ritual of a parent and a stepparent from the perspective of the stepchild. We sought to identify the various ritual forms of this ceremony and its significance (or lack thereof) for participants. Results inform us about the variety of ways this ritual is enacted and inform us, as well, about the perceived emptiness of the ritual. In answer to the first research question, we derived six basic types of remarriage ceremonies from the accounts provided by our sample of young-adult stepchildren. Five of the ceremonies centered on the marital pair, and the least common was the family-centered ceremony. These young-adult stepchildren perceived this family-centered ceremony as one that paid homage to the whole stepfamily - both the marital pair and all of the stepchildren. In response to the second research question, we examined the meaningfulness of remarriage ceremonies for these stepchildren, identifying three characteristics that differentiated meaningful from empty ritual enactments: (i) the type of ritual; (ii) the legitimation of the 'sacred object' (in most cases the marriage); and (iii) the stepchildren's degree of involvement in the ceremony. The majority of our participants experienced the remarriage ceremony as empty. Our findings hold implications for both 
ritual theory and for practitioners who work with stepfamily couples who are planning a remarriage ceremony.

The results of our study lend support in three ways to the arguments advanced by several family ritual theorists with respect to empty and meaningful rituals. First, as Wolin and Bennett (1984) argued, an empty ritual is likely to display nonadaptiveness. Nonadaptivity was, in part, based on the form of the remarriage ceremony. For many of the stepchildren in our sample, the parent and the stepparent failed to adapt the traditional 'white wedding' form to one deemed more appropriate for a remarriage. Other stepchildren faulted the ceremony because it was too casual and informal, thereby failing to mark adequately the transition of the couple from a cohabiting pair to their legal status as spouses. Both of these errors of form evidence a perception that the couple did not adequately appreciate that they were entering a new relational state distinctly different from a first marriage. The remarriage event was sometimes also nonadaptive in its failure to be responsive to the needs of the stepchildren, which segues to the second and third ways in which our results support theorizing about empty rituals.

Consistent with Wolin and Bennett's (1984) second argument - that a ritual can be empty if its participants are not committed to the act of ritualizing - we found that the meaningfulness of the parent-stepparent remarriage ceremony depended on the stepchildren's perception that they were involved in the ritual. The vast majority of remarriage ceremonies were empty in their exclusive focus on the couple and their marriage, to the relative neglect of the stepchildren. Many stepchildren in the sample felt that they were inadequately involved in the courtship between the parent and stepparent; they felt that the parent had been too hasty in the decision to remarry, and they further reported that they had insufficient time to get to know the stepparent and step-relations. These stepchildren wanted to be consulted, or at least informed, about the decision to marry. The desire to be informed or consulted about the remarriage is consistent with what other scholars have found concerning stepchildren's desire to be in the information loop in stepfamilies without being over-burdened with information that is too adult for them (Afifi, 2003; Braithwaite, Toller, Daas, Durham \& Jones, 2008).

Third, consistent with the argument of dialectically based ritual theorists, meaningful remarriage rituals paid homage to all of the competing demands simultaneously. As relational dialectics theory (Baxter \& Montgomery, 1996) posits, contradictions are often complex, with more than two competing demands. Implicated in the remarriage event are three competing meaning domains: The couple's marriage; the family-of-origin; and the stepfamily. For the stepchildren in the present study, it was important that the ritual was enacted in such a way that it honored their role as part of a stepfamily while, at the same time, legitimizing their family of origin. Instead, the typical participant perceived that the marriage of the parent and the stepparent was the sole focus of celebration, often at the cost of the memory of the family of origin and the new family unit legally created through the remarriage ceremony. Further, many stepchildren did not legitimate the marriage as a sacred object.The sense that the marriage was privileged over the stepfamily is consistent with Cissna, Cox, and Bochner's (1990) study of stepfamilies, where the adults centered their marriage above their relations with the (step)children. Our findings also are reflective of the Braithwaite et al. (1998) study of stepfamily rituals, which found that successful stepfamily rituals were ones that honored both the old and new families simultaneously. For the marrying couple, the remarriage ceremony formally marks the end of a difficult time and the beginning of a new, seemingly better, period. However, the stepchildren are clearly in a different emotional place, in transition from one difficult time - the end of life 
in the family of origin and the transitional family life that followed - to a different family system that may hold its own challenges. Parents, in their excitement to legalize their relationship with the new partner, may have lost track of what their children were going through surrounding the formation of a stepfamily. Stepchildren felt that neither the family of origin (and the transitional family that followed) nor the stepfamily as a unit was honored.

From an outsider perspective, our sample of young-adult stepchildren may appear to hold an overly romanticized view of what a marriage ceremony ought to be, especially with respect to traditions associated with the 'white wedding.' In addition, our participants may appear to be very judgmental with respect to parental behavior.We do not know the extent to which their views are developmental. It would be productive for future researchers to examine older stepchildren's perceptions of remarriage ceremonies When stepchildren have themselves married and established families of their own, realizing how complicated relational life can become, their reactions to parental remarriage may differ from those expressed by our sample.

Taken as a whole, the findings of this study present both challenges and opportunities for parents planning remarriage ceremonies. Children valued those rituals that celebrated the formalization of the stepfamily without sending the message that their old family was lacking. Parents need to be mindful of how their remarriage ceremony can simultaneously honor their marriage and at the same time explicitly celebrate the stepfamily as a unit. There was not one right way to do this in these present data, but stepchildren looked for evidence that they were included and that this was a family celebration rather than merely a couple celebration. Whether it was being granted sufficient time to get to know the stepparent, being informed and consulted about the decision to marry, participating in the planning of the ritual, or creating a ceremony and/or artifacts that celebrated the family, the result was that those families that could successfully negotiate the couple/familyof-origin/stepfamily dialectic created a ritual that was meaningful rather than empty for their children.

While the present study has its strengths, as with all studies there are limitations that provide opportunities for future researchers. We are mindful that our data only represent the perspective of the stepchild in the family. Clearly we need to do the same systematic work with parents and stepparents to discover their perspectives on the remarriage ritual in order to better understand the family dynamics that go into the planning and enactment of these rituals. Second, our sample was made up of college-educated, Caucasian

students. Future research needs to examine the experiences of non-white stepchildren and those who do not attend college.Third, we are also mindful that stepfamilies operate in larger social webs and we are interested in the role and perspective of extended family members regarding this ritual. Fourth, to the extent possible, researchers will benefit from a process perspective on meaningful and empty rituals (Baxter \& Braithwaite, 2006).We have little idea how the remarriage ritual develops in the stepfamily and at what point emptiness becomes most pronounced.We also know little about whether and how these remarriage rituals are negotiated in the family. Understanding family communication about the remarriage rituals may have practical implications for stepfamilies wanting to have a positive stepfamily identity. 


\section{References}

Afifi, T. D. (2003). 'Feeling caught' in stepfamilies: Managing boundary turbulence through appropriate privacy coordination rules. Journal of Social and Personal Relationships, 20, 729-756.

Altman, I., Brown, B. B., Staples, B., \& Werner, C.M. (1992). A transactional approach to close relationships: Courtship, weddings and placemaking. In B.Walsh, K. Craik, \& R. Price (Eds.), Person-environment psychology (pp. 193-241). Hillsdale, NJ: Erlbaum.

Altman, I., \& Ginat, J. (1996). Polygamous families in contemporary society. New York: Cambridge University Press.

Amato, P. R. (1994). The implications of research findings on children in stepfamilies. In A. Booth \& J. Dunn (Eds.), Stepfamilies: Who benefits? Who does not? (pp. 81-87). Hillsdale, NJ: Erlbaum.

Baxter, L.A. (2004). Distinguished scholar article: Relationships as dialogues. Personal Relationships, 11, 1-22.

Baxter, L.A., \& Braithwaite, D. O. (2002). Performing marriage: The marriage renewal ritual as cultural performance. Southern Communication Journal, 67, 94-109.

Baxter, L.A., \& Braithwaite, D. O. (2006). Rituals as communication constituting families. In L. Turner \& R. West (Eds.), Family communication: A reference of theory and research (pp. 259-280). Thousand Oaks, CA: Sage.

Baxter, L.A., \& Montgomery, B.M. (1996). Relating: Dialogues and dialectics. New York: The Guilford Press.

Bennett, L. A.,Wolin, S. J., Reiss, D., \& Teitlebaum, M. A. (1987). Couples at risk for transmission of alcoholism: Protective influences. Family Process, 26, 111-129.

Bossard, J. H. S., \& Boll, E. S. (1950). Ritual in family living: A contemporary study. Philadelphia, PA: University of Pennsylvania Press.

Braithwaite, D. O. (1995). Ritualized embarrassment at 'coed' wedding and baby showers. Communication Reports, 8, 145-157.

Braithwaite, D. O., \& Baxter, L. A. (1995). 'I do' again: The relational dialectics of renewing marriage vows. Journal of Social and Personal Relationships, 12, 177-198.

Braithwaite, D. O., Baxter, L. A., \& Harper, A. M. (1998). The role of rituals in the management of the dialectical tension of 'old' and 'new' in blended families. Communication Studies, 48, 101-120.

Braithwaite,D.O.,Toller, P., Daas, K., Durham,W.,\& Jones,A. (2008). Centered, but not caught in the middle: Stepchildren's perceptions of contradictions of communication of co-parents. Journal of Applied Communication Research, 36, 33-55.

Brown, B., Werner, C., \& Altman, I. (1998). Choice points for dialecticians: A dialecticaltransactional perspective on close relationships. In B. M. Montgomery \& L.A. Baxter (Eds.), Dialectical approaches to studying personal relationships (pp. 137-154). Mahwah, NJ: Erlbaum.

Bruess, C., \& Pearson, J. C. (1997). Interpersonal rituals in marriage and adult friendship. Communication Monographs, 64, 25-46.

Cate, R. M., \& Lloyd, S. A. (1992). Courtship. Newbury Park, CA: Sage.

Cheal, D. J. (1988). Relationships in time: Ritual, social structure, and the life course. Studies in Symbolic Interaction, 9, 83-109.

Cissna, K. N., Cox, D. E., \& Bochner, A. P. (1990). The dialectic of marital and parental relationships within the stepfamily. Communication Monographs, 57, 44-61.

Coleman, M., Ganong, L. H., \& Fine, M. (2000). Reinvestigating remarriage: Another decade of progress. Journal of Marriage and the Family, 62, 1288-1307. 
Deinham, S. (2003). Relationships between family rituals, family routines, and health. Journal of Family Nursing, 9, 305-330.

Fiese, B. H. (1992). Dimensions of family rituals across two generations: Relations to adolescent identity. Family Process, 31, 151-162.

Ganong, L. H., \& Coleman, M. (2004). Stepfamily relationships: Development, dynamics, and interventions. New York: Kluwer Academic, Plenum.

Holmberg, D., Orbuch, T. L., \& Veroff, J. (2003). Thrice told tales: Married couples tell their stories. Mahwah, NJ: Erlbaum.

Leeds-Hurwitz,W. (2002). Wedding as text: Communicating cultural identities through ritual. Mahwah, NJ: Erlbaum.

Lindlof, T. R., \& Taylor, B. C. (2002). Qualitative communication research methods (2nd ed.). Newbury Park, CA: Sage.

Lincoln,Y. S., \& Guba, E. G. (1985). Naturalistic inquiry. Newbury Park, CA: Sage.

McCracken, G. (1988). The long interview. Newbury Park, CA: Sage.

Oswald, R. F. (2000). A member of the wedding? Heterosexism and family ritual. Journal of Social and Personal Relationships, 17, 349-368.

Turner,V. (1957). Schism and continuity in an African society: A study of Ndembu village life. Manchester: Manchester University Press.

Turner, V. (1969). The ritual process: Structure and anti-structure. Ithaca, NY: Cornell University Press.

Turner,V. (1974). Dramas, fields, and metaphors: Symbolic action in human society. Ithaca,NY: Cornell University Press.

Werner,C.M.,Altman, I., Brown,B.,\& Ginat, J. (1993). Celebrations in personal relationships: A transactional/dialectical perspective. In S. Duck (Ed.), Social context and relationships (pp. 109-139). Newbury Park, CA: Sage.

Wolin, S. J., \& Bennett, L. A. (1984). Family rituals. Family Process, 23, 401-420. 